\title{
The detective, prognostic, and predictive value of DNA methylation in human esophageal squamous cell carcinoma
}

\author{
Kai Ma', Baoping $\mathrm{Cao}^{2}$ and Mingzhou Guo ${ }^{2 *}$
}

\begin{abstract}
Esophageal cancer is one of the most common malignancies in the world. Squamous cell carcinoma accounts for approximately $90 \%$ of esophageal cancer cases. Genetic and epigenetic changes have been found to accumulate during the development of various cancers, including esophageal squamous carcinoma (ESCC). Tobacco smoking and alcohol consumption are two major risk factors for ESCC, and both tobacco and alcohol were found to induce methylation changes in ESCC. Growing evidence demonstrates that aberrant epigenetic changes play important roles in the multiple-step processes of carcinogenesis and tumor progression. DNA methylation may occur in the key components of cancer-related signaling pathways. Aberrant DNA methylation affects genes involved in cell cycle, DNA damage repair, Wnt, TGF- $\beta$, and NF-KB signaling pathways, including P16, MGMT, SFRP2, DACH1, and ZNF382. Certain genes methylated in precursor lesions of the esophagus demonstrate that DNA methylation may serve as esophageal cancer early detection marker, such as methylation of HIN1, TFPI-2, DACH1, and SOX17. CHFR methylation is a late stage event in ESCC and is a sensitive marker for taxanes in human ESCC. FHIT methylation is associated with poor prognosis in ESCC. Aberrant DNA methylation changes may serve as diagnostic, prognostic, and chemo-sensitive markers. Characterization of the DNA methylome in ESCC will help to better understand its mechanisms and develop improved therapies.
\end{abstract}

Keywords: DNA methylation, Esophageal cancer, Epigenome, CHFR, Wnt signaling, DNA damage repair

\section{Background}

Esophageal carcinoma is the sixth leading cause of cancer-related mortality and the eighth most common cancer worldwide [1]. Esophageal cancer has two main subtypes-esophageal squamous cell carcinoma (ESCC) and esophageal adenocarcinoma (EAC). ESCC is the predominant histological type and accounts for $90 \%$ of the cases of esophageal carcinoma worldwide [2]. Tobacco smoking and alcohol consumption are two major risk factors in ESCC [3-5], while gastroesophageal reflux disease (GERD) [6], obesity, and diet [7] were recognized as risk factors for EAC. Despite surgery or chemoradiotherapy, the prognosis of esophageal cancerstill remains poor with the overall 5-year survival ranging from 15 to $25 \%[2,8,9]$. The mechanisms involved in ESCC

\footnotetext{
* Correspondence: mzguo@hotmail.com

${ }^{2}$ Department of Gastroenterology and Hepatology, Chinese PLA General

Hospital, \#28 Fuxing Road, Beijing 100853, China

Full list of author information is available at the end of the article
}

remain unclear. Therefore, a clearer understanding of esophageal cancer and subsequent treatment advances are in urgent need.

Both aberrant genetic and epigenetic changes have been demonstrated to contribute to human ESCC initiation and progression [10-12]. This review focuses on recent advances involving DNA methylation and its clinical application in human ESCC.

\section{Epigenetic alterations induced by risk factors of ESCC}

As mentioned above, nutrition and the consumption of tobacco and alcohol contribute to ESCC carcinogenesis. Talukdar et al. found that promoter region hypermethylation is associated with tobacco consumption by analyzing a group of tumor suppressor genes in human ESCC [13]. Similar results were obtained from another group [14]. Tobacco contains 4-(methylnitro-samino)-1-(-3pyridyl)-1-butanone (also known as nicotine-derived nitrosamine ketone $(\mathrm{NNK})$ ) and Benzo[ $\alpha]$ pyrene, which 
were found to modulate DNA methylation. NNK induced hypermethylation of multiple tumor suppressor genes in liver and lung tumors of rat and mouse models [15-17]. Another study found that NNK attenuated DNMT1 degradation and also induced its nuclear accumulation resulting in subsequent hypermethylation of promoters of tumor suppressor genes in animal and human lung cancer [18]. Benzo[ $\alpha]$ pyrene diol epoxide (BPDE), a carcinogen present in tobacco smoke and environmental pollution, has been shown to induce gene mutations (such as in P53 and KRAS genes) in vitro [19-22]. A recent study demonstrated that BPDE induced $R A R \beta 2$ promoter region methylation by recruiting DNA (cytosine-5-)-methyltransferase 3 alpha (DNMT3A) to its promoter region [23]. Another group identified that promoter methylation of the fragile histidine triad (FHIT) gene in ESCC was significantly associated with exposure to tobacco smoke [24]. Methylation frequency of the mutS homolog 3 (MSH3) gene promoter was significantly higher in tumor samples from smokers compared to tumor samples from non-smokers [25]. P16 methylation is associated with occupational airborne dust exposures. The methylation rate of $p 16$ is 8.7 times higher in patients that have been exposed to occupational airborne dust compared to patients without such exposure [26].

Many epidemiological studies have consistently shown that alcohol consumption is an etiological factor of human ESCC. ESCC has a stronger association with alcohol consumption than cancers of other organ sites [27, 28]. Genetic polymorphisms of ethanolmetabolizing genes, such as acetaldehyde dehydrogenase (ALDH) and alcohol dehydrogenases (ADH), are associated with ESCC [29-31]. Tobacco use and alcohol drinking have synergistic effects on carcinogenesis, where combined use explained more than $61 \%$ of ESCC [32, 33]. In the liver, ethanol is oxidized to acetaldehyde by ADH [34, 35]. Chronic alcoholism increases the requirements for methyl groups and causes dietary methyl group deficiency [36]. Deficiency of S-adenosylmethionine, folate, and betaine due to destruction by acetaldehyde is common in alcoholics. Inhibition of methyl group transfer regulates the expression of genes involved in carcinogenesis $[37,38]$. Several studies have shown that alcohol is associated with global DNA hypomethylation and tumor suppressor gene promoter region hypermethylation in human esophageal, hepatic, and colorectal cancers [39].

\section{Aberrant DNA methylation changes in human ESCC}

Global genomic DNA hypomethylation and promoter region hypermethylation have been extensively studied in human cancers, including ESCC [10, 11, 40-43]. Aberrant DNA methylation is involved in the major components of cell cycle, DNA damage repair, and cancer-related signaling pathways.

\section{Cell cycle-related genes}

P14, p15, and p16 are cyclin-dependent kinase (CDK) inhibitors that negatively regulate the G1-S transition in the cell cycle. P16 is frequently methylated in ESCC, while methylation of $p 14$ and $p 15$ is relatively infrequent in ESCC [44]. P16 is methylated in precursor lesions of the esophagus. This suggests that P16 is involved in the early stages of esophageal carcinogenesis.

The RAS association domain family 1A (RASSF1A) is a microtubule-binding and stabilizing protein. RASSF1A interacts with microtubules and inhibits M-phase cell progression [45]. RASSF1A is frequently methylated in ESCC [46-48]. RASSF10 is a new member of the Rasassociation family. RASSF10 inhibits cell proliferation and induces G2/M phase arrest. RASSF10 is methylated in $44.3 \%$ of ESCC [49]. Checkpoint with FHA and ring finger (CHFR) is another protein involved in mitotic checkpoint regulation [50]. CHFR induced G2/M phase arrest in ESCC. CHFR is frequently methylated in various cancers [51-54]. CHFR is methylated in $45 \%$ of human invasive ESCC and infrequently methylated in esophageal early lesions, suggesting that CHFR methylation may serve as a late stage marker in ESCC. Methylation of CHFR sensitized ESCC cells to taxanes [54].

\section{DNA repair genes}

Fragile histidine triad (FHIT) is regarded as a "caretaker," and loss of this caretaker function initiates the onset of genome instability and cancer development [55]. In some tumors that are associated with environmental carcinogens, alterations in the FHIT gene occur quite early in the development of cancer [56]. FHIT is frequently methylated in the early stages of ESCC, and aberrant methylation of FHIT is associated with poor prognosis and tobacco exposure [24].

The mismatch repair (MMR) system recognizes basebase mismatches and insertion or deletion loops (IDLs) in double-stranded DNA to degrade the newly synthesized error region and re-synthesize the correct second strand according to the template [57]. The human MMR system includes MLH1, MLH3, MSH2, MSH6, PMS1, and PMS2 genes. Defective MMR increases mutation rates up to 1000 -fold and leads to microsatellite instability (MSI) to result in carcinogenesis [58]. Germline MMR mutation gives rise to hereditary nonpolyposis colorectal cancer (CRC) accounts for $\sim 3 \%$ of all CRCs. Human MMR deficiency is mainly happened to MLH1 and $\mathrm{MSH} 2$ genes. By contrast with HNPCC, sporadic cancers are rarely found to have mutations in the $M L H 1$ or $M S H 2$ genes. In the population-based studies, the prevalence of MSI among CRCs is approximately $15 \%$. 
Mismatch repair deficiency can be inherited mutations or biallelic $M L H 1$ promoter region hypermethylation [59]. Methylation may be served as "second hit" for carcinogenesis. MLH1 is frequently methylated in sporadic CRC and other tumors, while $\mathrm{MSH} 2$ was not methylated in any of the sporadic CRCs [60-62]. In human esophageal squamous cell carcinoma, $M L H 1$ and $M S H 2$ are methylated in $33-62 \%$ and $29-32 \%$ of cases, irrespectively [40, 44, 63]. The expression of MLH1 and MSH2 were silenced by promoter region hypermethylation $[44,64,65]$.

O6-methylguanine-DNA methyltransferase (MGMT) is a DNA damage repair enzyme that protects cells from $\mathrm{G}$ to A mutations by removing methyl or alkyl groups from guanine after chemical modification [66]. MGMT is frequently methylated in human ESCC, and methylation of MGMT sensitized ESCC to temozolomide treatment $[44,67]$.

\section{Wnt signaling pathway genes}

The canonical Wnt signaling pathway is involved in many biological processes, including embryogenesis and carcinogenesis $[68,69]$. The activated $\mathrm{Wnt} / \beta$-catenin signaling pathway may induce MYC, cyclin D1, and expression of other downstream genes, promoting cell proliferation, and leading to carcinogenesis. Numerous Wnt signaling components, including Wnt, secreted frizzled-related proteins (SFRPs), and $\beta$-catenin, are also of pivotal importance in the activation/inhibition of Wnt signaling.

Wnt signaling plays an important role in esophageal cancer initiation and progression [70]. Epigenetic regulation of key genes in the Wnt signaling pathway has been reported by several groups. SFRP1 is methylated in $95 \%$ of ESCC. SFRP2 is methylated in $83 \%$ of ESCC, and the expression of SFRP2 is regulated by promoter region hypermethylation [71]. SRY-box containing gene 17 (SOX17) is reported to play critical roles in the regulation of development and stem/precursor cell function through repression of Wnt pathway activity [72]. SOX17 is frequently methylated in ESCC, and methylation of SOX17 activated Wnt signaling. SOX17 methylation is an early detection marker and is related to patients' history of alcohol use [73]. Reduced expression of SOX17 is related to poor prognosis in ESCC [74]. Wht inhibitory factor-1 (WIF1), one of the most important Wnt antagonists, is frequently down-regulated by promoter region hypermethylation in various types of cancer $[75,76]$. Wnt-5a antagonizes Wnt signaling by promoting GSK-3-independent $\beta$-catenin degradation. Wnt-5a is frequently methylated in ESCC [77]. Adenomatous polyposis coli $(A P C)$ is methylated more frequently in human adenocarcinoma than in human ESCC [44, 78]. The 2-year survival rate is reduced in $A P C$-methylated patients [79].

\section{TGF- $\beta$ signaling pathway genes}

In cancer, transforming growth factor- $\beta$ (TGF- $\beta$ ) signaling regulates tumor initiation, progression, and metastasis through a diverse repertoire of tumor-cell-autonomous and host-tumor interactions $[80,81]$. TGF- $\beta$ is regarded to be both a tumor suppressor and an oncogene [82]. In human prostate cancer, overexpression of TGF- $\beta$ enhanced angiogenesis around the tumor, which increased the metastasis of prostate cancer. On the other hand, gallbladder tumors secrete TGF- $\beta$, which inhibits angiogenesis and results in reduced tumor growth. TGF- $\beta$ signaling acts as a tumor suppressor during breast carcinogenesis, while TGF- $\beta$ promotes breast cancer metastasis in the later stages [83].

The role of TGF- $\beta$ signaling in human ESCC has not been extensively studied. There are only a few reports on the epigenetic regulation of TGF- $\beta$ signaling in ESCC. The human runt-related transcription factor 3 (RUNX3), an important component of the TGF- $\beta$ signaling pathway, is deleted in a variety of human cancers, including ESCC. RUNX3 is frequently methylated in human ESCC [84]. Human Dachshund homologue 1 (DACH1) is a major component of the retinal determination gene network. Loss of DACH1 expression was found in breast, prostate, lung, endometrial, colorectal and hepatocellular carcinoma. DACH1 expression was regulated by promoter region hypermethylation in esophageal cancer. The methylation frequency increased with the progression of esophageal carcinogenesis. DACH1 methylation is associated with poor differentiation and late tumor stage. Both in vivo and in vitro studies have demonstrated that DACH1 suppresses human esophageal cancer growth by activating TGF- $\beta$ signaling [85]. F-box protein 32 (FBXO32) is recently identified as a TGF- $\beta /$ Smad target gene [86]. FBXO32 is methylated in $52.3 \%$ of human ESCC and methylation of FBXO32 is associated with poor 5-year overall survival [87].

\section{NF-KB signaling pathway genes}

Nuclear factor- $\kappa B$ (NF- $\kappa B$ ) is a nuclear transcription factor. It was named NF- $k B$ because it was found bound to an enhancer element of the immunoglobulin kappa light chain gene in the nucleus of B cells [88, 89]. The Rel/ NF- $\mathrm{kB}$ transcription factor family is composed of several structurally related proteins including five cellular proteins: c-Rel, Rel A, Rel B, p50/p105, and p52/p100 [90]. Activation of NF- $\mathrm{kB}$ promotes cancer cell proliferation, invasion, and metastasis [91]. Sustained activation of NF- $\mathrm{KB}$ contributes to malignant progression and therapeutic resistance in most major human cancers [91, 92]. $\mathrm{NF}-\mathrm{KB}$ is involved in the process of carcinogenesis induced by infections and carcinogens (such as 7,12dimethylbenz(a)anthracene (DMBA)) in various cancers, including esophageal cancer [93-95]. 
The mechanism of NF- $\mathrm{KB}$ in ESCC remains to be elucidated. It has been reported that inhibition of NF-kB can increase the chemo-sensitivity of esophageal cancer (EC) cells in vitro [96]. The NF- $\mathrm{kB}$ inhibitor Bay11-7082 had significant antitumor effects on ESCC xenografts in nude mice by promoting apoptosis and inhibiting proliferation and angiogenesis, as well as reducing the metastasis of ESCC cells to the lungs, without significant toxic effects [97]. There are a limited number of studies on the epigenetic regulation of NF- $\mathrm{kB}$ signaling. It has been demonstrated that the zinc finger transcription factor, ZNF382, an inhibitor of NF-kB, is frequently methylated in human ESCC [98].

The application of DNA methylation markers in the clinic The best studied epigenetic modification is promoter region hypermethylation in tumor suppressor genes. DNA methylation represents the epigenetic biomarker with the highest translational potential due to its stable nature and reliable detection technologies [99]. DNA methylation patterns of certain genes may serve as early detection, prognostic, and chemo-sensitive markers, as well as therapeutic targets.

DNA methylation as ESCC detection and prognostic markers The epigenetic characteristics of ESCC are not well identified compared to other cancers, including esophageal adenocarcinoma. As LINE-1 elements constitute 17\% of the human genome, the methylation status of LINE-1 represents the global DNA methylation level [100]. LINE-1 methylation has been shown to be highly variable among ESCC specimens, LINE-1 hypomethylation is a marker of a poor prognosis in patients with early stage tumors, but not in those with advanced stage tumors [101]. Loss of imprinting (LOI) of insulin-like growth factor (IGF2) is associated with short time survival in ESCC [102]. The ten-eleven translocation (TET) family proteins can convert 5-methylcytosine $(5-\mathrm{mC})$ to 5hydroxymethylcytosine $(5-\mathrm{hmC})$, which is now widely recognized as the "sixth base" in the mammalian genome, following 5-mC, the "fifth base" [103-108]. Loss of 5-hmC is a poor prognostic marker in kidney cancer [109]. The levels of 5-hmC are reduced in human ESCC, and the levels of 5-hmC are related to histologic grade [110].

Promoter region hypermethylation is found frequently in ESCC. DNA methylation changes were shown to have a progression tendency during esophageal carcinogenesis and progression, suggesting that DNA methylation is an early event in ESCC. Our previous studies found that DAPK, p16, MGMT, MLH1, RARß2, HIN1, TFPI-2, $D A C H 1$, and $S O X 17$ were methylated in the precursor lesions of human esophageal epithelia [44, 73, 85, 111-113]. The methylation frequency increased with the progression of esophageal cancer. CHFR methylation is a late stage marker of ESCC [54]. Loss of CDH1 expression, a gene encoding E-cadherin, is related to tumor invasiveness, metastasis, and poor prognosis in ESCC. Methylation of CDH1 was detected in 14-61\% of ESCC tumors, and it was associated with the recurrence of early stage [44, 114-117]. RASSF1A hypermethylation was significantly correlated with poorly differentiated tumors and advanced tumor stage [47, 118, 119]. P16 methylation was associated with invasiveness and metastasis [120]. FHIT was methylated in the early stages of ESCC, and its methylation was associated with poor prognosis [24]. Our recent study found that DACT2 methylation is frequently methylated in human esophageal squamous dysplasia and ESCC. DACT2 methylation is associated with TNM stage and lymph node metastasis. These results suggest that DACT2 methylation may serve as ESCC early detective and prognostic markers. NKD2 is frequently methylated in human ESCC, and methylation of NKD2 is associated with TNM stage and lymph node metastasis (data not shown). Additional methylation markers for ESCC are listed in Table 1. DNA methylation may serve as a marker for early detection, tumor recurrence, and prognosis in ESCC.

\section{DNA methylation as a chemo-sensitive marker and thera- peutic target in ESCC}

Methylation patterns can be useful to assess clinical outcomes or response to chemotherapeutic agents. DNA methylation profiling has identified tumor-specific drug responsive markers in different cancers. The identification of biomarkers that predict response to chemotherapy is a component of precision medicine. For example, MGMT methylation was found to be associated with responsiveness to alkylator-based chemotherapy and an increase in overall survival and time to progression of gliomas [121]. In oxaliplatin-treated gastric cancer patients, overall survival was longer in the MLH1 unmethylated group compared to the MLH1 methylated group [60].

Many new epigenetic chemo-sensitive markers have been found in different cancer types [122]. Meanwhile, reports about DNA methylation patterns as chemosensitive markers in ESCC are very limited. CHFR is an early mitotic checkpoint gene that functions as a key player in controlling chromosomal integrity [123]. CHFR controls cell cycle progression at the G2/M checkpoint. Increased expression of CHFR leads to mitotic arrest. CHFR methylation is a sensitive marker for taxanes in human ESCC [54].

\section{Perspective}

The landscapes of cancer genomes have already had an impact on the clinical care of cancer patients. The recognition that certain tumors contain activating mutations in 
Table 1 Aberrantly methylated genes in ESCC

\begin{tabular}{|c|c|c|}
\hline Gene & Histological type (M\%) & Reference \\
\hline $\mathrm{HIN}-1$ & $\begin{array}{l}\text { LGD (31 \%), MGD (33 \%), } \\
\text { HGD (44\%), ESCC (50 \%) }\end{array}$ & [111] \\
\hline DAB2 & Dysplasia (67 \%), ESCC (68 \%) & [132] \\
\hline PGP9.5 & $\operatorname{ESCC}(42 \%)$ & [133] \\
\hline ECRG4 & ESCC (69 \%) & [134] \\
\hline APC & ESCC (50 \%), EAC (92\%) & [135] \\
\hline FHIT & ESCC (33\%) & [24] \\
\hline GNG7 & ESCC (33\%) & [136] \\
\hline $\mathrm{CDH} 1$ & $\operatorname{ESCC}(43 \%)$ & [137] \\
\hline Integrin a4 & ESCC (21 \%) & [137] \\
\hline Wif-1 & $\operatorname{ESCC}(35 \%)$ & [137] \\
\hline MGMT & $\begin{array}{l}\text { LGD (23 \%), MGD (17 \%), } \\
\text { HGD (11\%), ESCC (33\%) }\end{array}$ & [44] \\
\hline MLH1 & $\begin{array}{l}\operatorname{LGD}(8 \%), \operatorname{MGD}(17 \%) \\
\operatorname{HGD}(33 \%), \operatorname{ESCC}(23 \%)\end{array}$ & [44] \\
\hline RARß2 & $\begin{array}{l}\text { LGD (13\%), MGD (33 \%), } \\
\text { HGD (44\%), ESCC (36 \%) }\end{array}$ & [44] \\
\hline TFPI-2 & $\begin{array}{l}\text { LGD (28 \%), MGD (33\%), } \\
\text { HGD (33 \%), ESCC (67 \%) }\end{array}$ & [112] \\
\hline $\mathrm{DACH} 1$ & $\begin{array}{l}\text { LGD (19\%), MGD and } \\
\operatorname{HGD~(42\% ),~ESCC~(62~\% )~}\end{array}$ & [85] \\
\hline SOX17 & $\begin{array}{l}\text { LGD }(39 \%), \text { MGD and } \\
\text { HGD (48 \%), ESCC (65 \%) }\end{array}$ & [73] \\
\hline DAPK & $\begin{array}{l}\text { LGD (28 \%), MGD (25 \%), } \\
\operatorname{HGD}(11 \%), \operatorname{ESCC}(26 \%)\end{array}$ & {$[44]$} \\
\hline P16 & $\begin{array}{l}\text { LGD (31 \%), MGD (42 \%), } \\
\text { HGD (33\%), ESCC (52\%) }\end{array}$ & [44] \\
\hline CHFR & $\begin{array}{l}\operatorname{LGD}(2.9 \%), \operatorname{MGD}(0), \\
\operatorname{HGD}(12.5 \%), \operatorname{ESCC}(45 \%)\end{array}$ & [54] \\
\hline RASSF10 & $\operatorname{ESCC}(44.3 \%)$ & [49] \\
\hline ZNF331 & ESCC (56.5 \%) & [138] \\
\hline
\end{tabular}

$M \%$ methylation rate, $L G D$ low-grade dysplasia, $M G D$ middle-grade dysplasia, $H G D$ high-grade dysplasia, ESCC esophageal squamous carcinoma

driver genes encoding protein kinases has led to the development of small-molecule inhibitor drugs targeting those kinases [124]. However, the landscapes of the epigenome in all cancer types and their normal counterparts need to be completed. The Roadmap project for methylome mapping may generate more reference data sets for research and clinical use $[125,126]$.

Many DNA methylation markers have been reported for early detection, prognosis, therapeutic responsiveness, and therapeutic targets in different cancer types [127-130]. Targeting therapy based on aberrant genomic changes has already had an impact on the clinical care of cancer patients. While the value of epigenetic modifications in personalized medicines still not extensively studied. Epigenome-based personalized medicine may be suitable for human cancer patients with the recognition of cancer epigenome landscapes [131]. In ESCC, there are limited
DNA methylation markers for early detection, prognosis, and chemo-responsiveness. We are far from having a full understanding of the molecular mechanisms responsible for the initiation and maintenance of the epigenetic abnormalities that help drive tumorigenesis. Therefore, we must continue to develop epigenetic biomarkers in ESCC.

\section{Conclusions}

Epigenetic regulation of tumor suppressor gene expression plays an important role during esophageal carcinogenesis and progression. Aberrant DNA methylation patterns may serve as early detection, diagnostic, prognostic, and chemo-sensitive markers. While some important genes have already been identified to be frequently methylated in ESCC, mapping the landscape of the esophageal cancer epigenome has yet to be completed. Personalized therapy based on the ESCC epigenome will be developed in the future.

\section{Abbreviations}

ADH: alcohol dehydrogenases; ALDH: acetaldehyde dehydrogenase: APC: adenomatous polyposis coli; BPDE: Benzo[a]pyrene diol epoxide; CDK: cyclin-dependent kinase; CHFR: Checkpoint with FHA and ring finger; CRC: colorectal cancer; DACH1: Dachshund homologue 1; DNMT3A: DNA (cytosine-5-)-methyltransferase 3 alpha; EAC: esophageal adenocarcinoma; ESCC: esophageal squamous carcinoma; FBXO32: F-box protein 32; FHIT: fragile histidine triad; GERD: gastroesophageal reflux disease; IDLs: insertion or deletion loops; MGMT: O6-methylguanine-DNA methyltransferase; MMR: mismatch repair; MSH3: mutS homolog 3; MSI: microsatellite instability; NNK: 4-(methylnitro-samino)-1-(-3-pyridyl)-1butanone, also known as nicotine-derived nitrosamine ketone; RASSF1A: RAS association domain family 1A; RUNX3: human runt-related transcription factor 3; SFRPs: secreted frizzled-related proteins; SOX17: SRY-box containing gene 17; TGF- $\beta$ : transforming growth factor- $\beta$; WIF1: Wnt inhibitory factor-1.

\section{Competing interests}

The authors declare that they have no competing interests.

\section{Authors' contributions}

KM and BC wrote the manuscript. MG designed the manuscript structure and edited the manuscript. All authors read and approved the final version of manuscript.

\section{Acknowledgements}

This work was supported by the following grants: National Basic Research Program of China (973 Program No. 2012CB934002, 2015CB553904); National High-tech R\&D Program of China (863 Program No. SS2012AA020314, SS2012AA020821, SS2012AA020303); National Key Scientific Instrument Special Programme of China (Grant No. 2011YQ03013405); and National Natural Science Foundation of China (CN) (NSFC No.81402345, 81121004, 81161120432, 81490753, and 81401950).

\section{Author details}

${ }^{1}$ Department of Thoracic Surgery, the Affiliated Hospital of Qingdao University, Qingdao, China. ${ }^{2}$ Department of Gastroenterology and Hepatology, Chinese PLA General Hospital, \#28 Fuxing Road, Beijing 100853, China.

Received: 3 November 2015 Accepted: 14 April 2016

Published online: 22 April 2016

\section{References}

1. Ferlay J, Soerjomataram I, Dikshit R, Eser S, Mathers C, Rebelo M, et al. Cancer incidence and mortality worldwide: sources, methods and major patterns in GLOBOCAN 2012. Int J Cancer. 2015;136(5):E359-86. doi:10.1002/ijc.29210. 
2. Pennathur A, Gibson MK, Jobe BA, Luketich JD. Oesophageal carcinoma. Lancet. 2013;381(9864):400-12. doi:10.1016/s0140-6736(12)60643-6.

3. De Stefani E, Barrios E, Fierro L. Black (air-cured) and blond (flue-cured) tobacco and cancer risk. III: oesophageal cancer. Eur J Cancer. 1993;29A(5):763-6

4. Lee CH, Wu DC, Lee JM, Wu IC, Goan YG, Kao EL, et al. Carcinogenetic impact of alcohol intake on squamous cell carcinoma risk of the oesophagus in relation to tobacco smoking. Eur J Cancer. 2007;43(7): 1188-99. doi:10.1016/j.ejca.2007.01.039.

5. Vaughan TL, Davis S, Kristal A, Thomas DB. Obesity, alcohol, and tobacco as risk factors for cancers of the esophagus and gastric cardia: adenocarcinoma versus squamous cell carcinoma. Cancer Epidemiol Biomarkers Prev. 1995:4(2):85-92.

6. Lagergren J, Bergstrom R, Lindgren A, Nyren O. Symptomatic gastroesophageal reflux as a risk factor for esophageal adenocarcinoma. N Engl J Med. 1999;340:825-31.

7. Veugelers PJ, Porter GA, Guernsey DL, Casson AG. Obesity and lifestyle risk factors for gastroesophageal reflux disease, Barrett esophagus and esophageal adenocarcinoma. DisEsophagus. 2006;19:321-8.

8. Enzinger PC, Mayer RJ. Esophageal cancer. N Engl J Med. 2003;349(23): 2241-52. doi:10.1056/NEJMra035010.

9. Pennathur A, Farkas A, Krasinskas AM, Ferson PF, Gooding WE, Gibson MK, et al. Esophagectomy for $\mathrm{T} 1$ esophageal cancer: outcomes in 100 patients and implications for endoscopic therapy. Ann Thorac Surg. 2009;87(4): 1048-54. doi:10.1016/j.athoracsur.2008.12.060. discussion 54-5.

10. Ahrens TD, Werner M, Lassmann S. Epigenetics in esophageal cancers. Cell Tissue Res. 2014;356(3):643-55. doi:10.1007/s00441-014-1876-y.

11. Zhang XM, Guo MZ. The value of epigenetic markers in esophageal cancer. Front Med China. 2010;4(4):378-84. doi:10.1007/s11684-010-0230-3.

12. Kanwal R, Gupta S. Epigenetic modifications in cancer. Clinical genetics. 2012;81(4):303-11. doi:10.1111/j.1399-0004.2011.01809.x.

13. Talukdar FR, Ghosh SK, Laskar RS, Mondal R. Epigenetic, genetic and environmental interactions in esophageal squamous cell carcinoma from northeast India. PloS one. 2013;8(4):e60996. doi:10.1371/journal.pone.0060996.

14. Kulkarni V, Saranath D. Concurrent hypermethylation of multiple regulatory genes in chewing tobacco associated oral squamous cell carcinomas and adjacent normal tissues. Oral Oncol. 2004;40(2):145-53.

15. Pulling LC, Klinge DM, Belinsky SA. p16INK4a and beta-catenin alterations in rat liver tumors induced by NNK. Carcinogenesis. 2001;22(3):461-6.

16. Pulling LC, Vuillemenot BR, Hutt JA, Devereux TR, Belinsky SA. Aberrant promoter hypermethylation of the death-associated protein kinase gene is early and frequent in murine lung tumors induced by cigarette smoke and tobacco carcinogens. Cancer Res. 2004;64(11):3844-8. doi:10.1158/0008-5472.can-03-2119.

17. Vuillemenot BR, Hutt JA, Belinsky SA. Gene promoter hypermethylation in mouse lung tumors. Mol Cancer Res. 2006;4(4):267-73. doi:10.1158/15417786. mcr-05-0218.

18. Lin RK, Hsieh YS, Lin P, Hsu HS, Chen CY, Tang YA, et al. The tobaccospecific carcinogen NNK induces DNA methyltransferase 1 accumulation and tumor suppressor gene hypermethylation in mice and lung cancer patients. J Clin Invest. 2010;120(2):521-32. doi:10.1172/jci40706.

19. Denissenko MF, Pao A, Tang M, Pfeifer GP. Preferential formation of benzo[a]pyrene adducts at lung cancer mutational hotspots in P53. Science. 1996;274(5286):430-2.

20. Mass MJ, Jeffers AJ, Ross JA, Nelson G, Galati AJ, Stoner GD, et al. Ki-ras oncogene mutations in tumors and DNA adducts formed by benz[j]aceanthrylene and benzo[a]pyrene in the lungs of strain $\mathrm{A} / \mathrm{J}$ mice. Mol Carcinog. 1993;8(3):186-92

21. Venkatachalam S, Denissenko MF, Alvi N, Wani AA. Rapid activation of apoptosis in human promyelocytic leukemic cells by (+/-)-antibenzo[a]pyrene diol epoxide induced DNA damage. Biochem Biophys Res Commun. 1993;197(2):722-9. doi:10.1006/bbrc.1993.2539.

22. Wang D, You L, Sneddon J, Cheng SJ, Jamasbi R, Stoner GD. Frameshift mutation in codon 176 of the p53 gene in rat esophageal epithelial cells transformed by benzo[a]pyrene dihydrodiol. Mol Carcinog. 1995;14(2):84-93

23. Ye F, Xu XC. Benzo[a]pyrene diol epoxide suppresses retinoic acid receptorbeta2 expression by recruiting DNA (cytosine-5-)-methyltransferase 3A. Mol Cancer. 2010;9:93. doi:10.1186/1476-4598-9-93.

24. Lee EJ, Lee BB, Kim JW, Shim YM, Hoseok I, Han J, et al. Aberrant methylation of Fragile Histidine Triad gene is associated with poor prognosis in early stage esophageal squamous cell carcinoma. European journal of cancer (Oxford, England: 1990). 2006;42(7):972-80 doi:10.1016/j.ejca.2006.01.021

25. Vogelsang M, Paccez JD, Schafer G, Dzobo K, Zerbini LF, Parker MI. Aberrant methylation of the MSH3 promoter and distal enhancer in esophageal cancer patients exposed to first-hand tobacco smoke. Journal of cancer research and clinical oncology. 2014. doi:10.1007/s00432-014-1736-x.

26. Mohammad Ganji S, Miotto E, Callegari E, Sayehmiri K, Fereidooni F, Yazdanbod $\mathrm{M}$, et al. Associations of risk factors obesity and occupational airborne exposures with CDKN2A/p16 aberrant DNA methylation in esophageal cancer patients. Diseases of the esophagus : official journal of the International Society for Diseases of the Esophagus / ISDE. 2010;23(7): 597-602. doi:10.1111/j.1442-2050.2010.01059.x.

27. Bagnardi V, Blangiardo M, La Vecchia C, Corrao G. A meta-analysis of alcohol drinking and cancer risk. Br J Cancer. 2001;85(11):1700-5. doi:10.1054/bjoc.2001.2140

28. Liu Y, Chen H, Sun Z, Chen X. Molecular mechanisms of ethanol-associated oro-esophageal squamous cell carcinoma. Cancer Lett. 2015;361(2):164-73. doi:10.1016/j.canlet.2015.03.006

29. Oze I, Matsuo K, Suzuki T, Kawase T, Watanabe M, Hiraki A, et al. Impact of multiple alcohol dehydrogenase gene polymorphisms on risk of upper aerodigestive tract cancers in a Japanese population. Cancer Epidemiol Biomarkers Prev. 2009;18(11):3097-102. doi:10.1158/1055-9965.epi-09-0499.

30. Tanaka F, Yamamoto K, Suzuki S, Inoue H, Tsurumaru M, Kajiyama Y, et al. Strong interaction between the effects of alcohol consumption and smoking on oesophageal squamous cell carcinoma among individuals with ADH1B and/or ALDH2 risk alleles. Gut. 2010;59(11):1457-64. doi:10.1136/gut.2009.205724

31. Wu C, Kraft P, Zhai K, Chang J, Wang Z, Li Y, et al. Genome-wide association analyses of esophageal squamous cell carcinoma in Chinese identify multiple susceptibility loci and gene-environment interactions. Nat Genet. 2012;44(10):1090-7. doi:10.1038/ng.2411.

32. Anantharaman D, Marron M, Lagiou P, Samoli E, Ahrens W, Pohlabeln H, et al. Population attributable risk of tobacco and alcohol for upper aerodigestive tract cancer. Oral Oncol. 2011;47(8):725-31. doi:10.1016/j.oraloncology.2011.05.004.

33. Pelucchi C, Gallus S, Garavello W, Bosetti C, La Vecchia C. Cancer risk associated with alcohol and tobacco use: focus on upper aero-digestive tract and liver. Alcohol Res Health. 2006;29(3):193-8.

34. Bell-Parikh LC, Guengerich FP. Kinetics of cytochrome P450 2E1-catalyzed oxidation of ethanol to acetic acid via acetaldehyde. J Biol Chem. 1999;274(34):23833-40.

35. Kunitoh S, Imaoka S, Hiroi T, Yabusaki Y, Monna T, Funae Y. Acetaldehyde as well as ethanol is metabolized by human CYP2E1. J Pharmacol Exp Ther. 1997;280(2):527-32.

36. Seitz HK, Stickel F. Molecular mechanisms of alcohol-mediated carcinogenesis. Nat Rev Cancer. 2007;7(8):599-612. doi:10.1038/nrc2191.

37. Lu SC, Mato JM. Role of methionine adenosyltransferase and Sadenosylmethionine in alcohol-associated liver cancer. Alcohol. 2005;35(3): 227-34. doi:10.1016/j.alcohol.2005.03.011.

38. Mason JB, Choi SW. Effects of alcohol on folate metabolism: implications for carcinogenesis. Alcohol. 2005;35(3):235-41. doi:10.1016/j.alcohol.2005.03.012.

39. Varela-Rey M, Woodhoo A, Martinez-Chantar ML, Mato JM, Lu SC. Alcohol, DNA methylation, and cancer. Alcohol Res. 2013;35(1):25-35.

40. Baba $Y$, Watanabe $\mathrm{M}, \mathrm{Baba} \mathrm{H}$. Review of the alterations in DNA methylation in esophageal squamous cell carcinoma. Surg Today. 2013;43(12):1355-64. doi:10.1007/s00595-012-0451-y.

41. Guo M, Yan W. Epigenetics of gastric cancer. Methods Mol Biol. 2015;1238: 783-99. doi:10.1007/978-1-4939-1804-1_41.

42. Jia Y, Guo M. Epigenetic changes in colorectal cancer. Chin J Cancer. 2013; 32(1):21-30. doi:10.5732/cjc.011.10245.

43. Yan W, Guo M. Epigenetics of colorectal cancer. Methods Mol Biol. 2015 1238:405-24. doi:10.1007/978-1-4939-1804-1_22.

44. Guo M, Ren J, House MG, Qi Y, Brock MV, Herman JG. Accumulation of promoter methylation suggests epigenetic progression in squamous cell carcinoma of the esophagus. Clin Cancer Res. 2006;12(15):4515-22. doi:10. 1158/1078-0432.ccr-05-2858.

45. Rong R, Jiang LY, Sheikh MS, Huang Y. Mitotic kinase Aurora-A phosphorylates RASSF1A and modulates RASSF1A-mediated microtubule interaction and M-phase cell cycle regulation. Oncogene. 2007;26(55): 7700-8. doi:10.1038/sj.onc.1210575. 
46. Du Z, Ma K, Sun X, Li A, Wang H, Zhang L, et al. Methylation of RASSF1A gene promoter and the correlation with DNMT1 expression that may contribute to esophageal squamous cell carcinoma. World J Surg Oncol. 2015:13(1):141. doi:10.1186/s12957-015-0557-y.

47. Kuroki T, Trapasso F, Yendamuri S, Matsuyama A, Alder H, Mori M, et al. Promoter hypermethylation of RASSF1A in esophageal squamous cell carcinoma. Clin Cancer Res. 2003;9(4):1441-5.

48. Mao WM, Li P, Zheng QQ, Wang CC, Ge MH, Hu FJ, et al. Hypermethylationmodulated downregulation of RASSF1A expression is associated with the progression of esophageal cancer. Arch Med Res. 2011;42(3):182-8. doi:10. 1016/j.arcmed.2011.04.002.

49. Lu D, Ma J, Zhan Q, Li Y, Qin J, Guo M. Epigenetic silencing of RASSF10 promotes tumor growth in esophageal squamous cell carcinoma. Discov Med. 2014;17(94):169-78

50. Summers MK, Bothos J, Halazonetis TD. The CHFR mitotic checkpoint protein delays cell cycle progression by excluding Cyclin B1 from the nucleus. Oncogene. 2005;24(16):2589-98. doi:10.1038/sj.onc.1208428.

51. Guo H, Yan W, Yang Y, Guo M. Promoter region methylation of DNA damage repair genes in human gastric cancer. Zhonghua Yi Xue Za Zhi. 2014;94(28):2193-6.

52. Guo M, Alumkal J, Drachova T, Gao D, Marina SS, Jen J, et al. CHFR methylation strongly correlates with methylation of DNA damage repair and apoptotic pathway genes in non-small cell lung cancer. Discov Med. 2015:19(104):151-8.

53. Vitiello M, Tuccoli A, Poliseno L. Long non-coding RNAs in cancer: implications for personalized therapy. Cell Oncol (Dordr). 2015;38(1):17-28. doi:10.1007/s13402-014-0180-X.

54. Yun T, Liu Y, Gao D, Linghu E, Brock MV, Yin D, et al. Methylation of CHFR sensitizes esophageal squamous cell cancer to docetaxel and paclitaxel. Genes Cancer. 2015;6(1-2):38-48.

55. Waters CE, Saldivar JC, Hosseini SA, Huebner K. The FHIT gene product: tumor suppressor and genome "caretaker". Cellular and molecular life sciences : CMLS. 2014;71(23):4577-87. doi:10.1007/s00018-014-1722-0.

56. Croce CM, Sozzi G, Huebner K. Role of FHIT in human cancer. Journal of clinical oncology : official journal of the American Society of Clinical Oncology. 1999;17(5):1618-24.

57. Hsieh P, Yamane K. DNA mismatch repair: molecular mechanism, cancer, and ageing. Mechanisms of ageing and development. 2008;129(7-8): 391-407. doi:10.1016/j.mad.2008.02.012.

58. Curtin NJ. DNA repair dysregulation from cancer driver to therapeutic target. Nat Rev Cancer. 2012;12(12):801-17. doi:10.1038/nrc3399.

59. Boland $C R$, Goel A. Microsatellite instability in colorectal cancer. Gastroenterology. 2010;138(6):2073-87. doi:10.1053/j.gastro.2009.12.064. e3.

60. Li Y, Yang Y, Lu Y, Herman JG, Brock MV, Zhao P, et al. Predictive value of CHFR and MLH1 methylation in human gastric cancer. Gastric Cancer. 2015; 18(2):280-7. doi:10.1007/s10120-014-0370-2.

61. Matsushita M, Takeuchi S, Yang Y, Yoshino N, Tsukasaki K, Taguchi H, et al. Methylation of the MLH1 gene in hematological malignancies. Oncol Rep. 2005;14(1):191-4.

62. Shigeyasu K, Nagasaka T, Mori Y, Yokomichi N, Kawai T, Fuji T, et al, Clinical significance of MLH1 methylation and $\mathrm{CpG}$ island methylator phenotype as prognostic markers in patients with gastric cancer. PLoS One. 2015;10(6):e0130409. doi:10.1371/journal.pone.0130409.

63. Ling ZQ, Li P, Ge MH, Hu FJ, Fang XH, Dong ZM, et al. Aberrant methylation of different DNA repair genes demonstrates distinct prognostic value for esophageal cancer. Dig Dis Sci. 2011;56(10):2992-3004. doi:10.1007/s10620-011-1774-z.

64. Su Y, Yin L, Liu R, Sheng J, Yang M, Wang Y, et al. Promoter methylation status of MGMT, hMSH2, and hMLH1 and its relationship to corresponding protein expression and TP53 mutations in human esophageal squamous cell carcinoma. Medical oncology (Northwood, London, England). 2014; 31(2):784. doi:10.1007/s12032-013-0784-4.

65. Tzao C, Hsu HS, Sun GH, Lai HL, Wang YC, Tung HJ, et al. Promoter methylation of the hMLH1 gene and protein expression of human mutL homolog 1 and human mutS homolog 2 in resected esophageal squamous cell carcinoma. The Journal of thoracic and cardiovascular surgery. 2005; 130(5):1371. doi:10.1016/j.jtcvs.2005.06.004.

66. Zhao JJ, Li HY, Wang D, Yao H, Sun DW. Abnormal MGMT promoter methylation may contribute to the risk of esophageal cancer: a meta-analysis of cohort studies. Tumour biology : the journal of the
International Society for Oncodevelopmental Biology and Medicine. 2014. doi:10.1007/s13277-014-2276-3.

67. Hasina R, Surati M, Kawada I, Arif Q, Carey GB, Kanteti R, et al. O-6methylguanine-deoxyribonucleic acid methyltransferase methylation enhances response to temozolomide treatment in esophageal cancer. Journal of carcinogenesis. 2013;12:20. doi:10.4103/1477-3163.120632.

68. Clevers H. Wnt/beta-catenin signaling in development and disease. Cell. 2006;127(3):469-80. doi:10.1016/j.cell.2006.10.018.

69. Klaus A, Birchmeier W. Wnt signalling and its impact on development and cancer. Nat Rev Cancer. 2008;8(5):387-98. doi:10.1038/nrc2389.

70. Clement G, Braunschweig R, Pasquier N, Bosman FT, Benhattar J. Alterations of the Wnt signaling pathway during the neoplastic progression of Barrett's esophagus. Oncogene. 2006;25(21):3084-92. doi:10.1038/sj.onc.1209338.

71. Saito T, Mitomi H, Imamhasan A, Hayashi T, Mitani K, Takahashi M, et al. Downregulation of sFRP-2 by epigenetic silencing activates the beta-catenin/Wnt signaling pathway in esophageal basaloid squamous cell carcinoma. Virchows Archiv : an international journal of pathology. 2014;464(2):135-43. doi:10.1007/s00428-014-1538-1.

72. Gubbay J, Collignon J, Koopman P, Capel B, Economou A, Munsterberg A, et al. A gene mapping to the sex-determining region of the mouse $Y$ chromosome is a member of a novel family of embryonically expressed genes. Nature. 1990;346(6281):245-50. doi:10.1038/346245a0.

73. Jia Y, Yang Y, Zhan Q, Brock MV, Zheng X, Yu Y, et al. Inhibition of SOX17 by microRNA 141 and methylation activates the WNT signaling pathway in esophageal cancer. J Mol Diagn. 2012;14(6):577-85. doi:10.1016/j.jmoldx. 2012.06.004

74. Kuo IY, Wu CC, Chang JM, Huang YL, Lin CH, Yan JJ, et al. Low SOX17 expression is a prognostic factor and drives transcriptional dysregulation and esophageal cancer progression. International journal of cancer Journal international du cancer. 2014;135(3):563-73. doi:10.1002/ijc.28695.

75. Roperch JP, Incitti R, Forbin S, Bard F, Mansour H, Mesli F, Baumgaertner I, Brunetti F, Sobhani I. Aberrant methylation of NPY, PENK, and WIF1 as a promising marker for blood-based diagnosis of colorectal cancer. BMC Cancer. 2013;13. doi:10.1186/1471-2407-13-566.

76. Veeck J, Wild PJ, Fuchs T, Schüffler PJ, Hartmann A, Knüchel R, Dahl E. Prognostic relevance of Wnt-inhibitory factor-1 (WIF1) and Dickkopf-3 (DKK3) promoter methylation in human breast cancer. BMC cancer. 2009;9. doi:10.1186/1471-2407-9-217

77. Li J, Ying J, Fan Y, Wu L, Ying Y, Chan AT, et al. WNT5A antagonizes WNT/ beta-catenin signaling and is frequently silenced by promoter $\mathrm{CpG}$ methylation in esophageal squamous cell carcinoma. Cancer biology \& therapy. 2010;10(6):617-24.

78. Brock MV, Gou M, Akiyama Y, Muller A, Wu T, Montgomery E, et al. Prognostic importance of promoter hypermethylation of multiple genes in esophageal adenocarcinoma. Clin Cancer Res. 2003;9(8):2912-9.

79. Zare M, Jazii FR, Alivand MR, Nasseri NK, Malekzadeh R, Yazdanbod M. Qualitative analysis of adenomatous polyposis Coli promoter: hypermethylation, engagement and effects on survival of patients with esophageal cancer in a high risk region of the world, a potential molecular marker. BMC cancer. 2009;9:24. doi:10.1186/1471-2407-9-24.

80. Siegel PM, Massague J. Cytostatic and apoptotic actions of TGF-beta in homeostasis and cancer. Nat Rev Cancer. 2003;3(11):807-21. doi:10.1038/ nrc1208.

81. Bierie B, Moses HL. TGF-beta and cancer. Cytokine Growth Factor Rev. 2006; 17(1-2):29-40. doi:10.1016/j.cytogfr.2005.09.006.

82. Pardali K, Moustakas A. Actions of TGF-beta as tumor suppressor and prometastatic factor in human cancer. Biochim Biophys Acta. 2007;1775(1):2162. doi:10.1016/j.bbcan.2006.06.004.

83. Imamura T, Hikita A, Inoue $Y$. The roles of TGF-beta signaling in carcinogenesis and breast cancer metastasis. Breast Cancer. 2012;19(2):11824. doi:10.1007/s12282-011-0321-2.

84. Zheng Y, Zhang Y, Huang X, Chen L. Analysis of the RUNX3 gene methylation in serum DNA from esophagus squamous cell carcinoma, gastric and colorectal adenocarcinoma patients. Hepatogastroenterology. 2011;58(112):2007-11. doi:10.5754/hge10016.

85. Wu L, Herman JG, Brock MV, Wu K, Mao G, Yan W, et al. Silencing DACH1 promotes esophageal cancer growth by inhibiting TGF-beta signaling. PLoS One. 2014;9(4):e95509. doi:10.1371/journal.pone.0095509.

86. Qin H, Chan MW, Liyanarachchi S, Balch C, Potter D, Souriraj IJ, et al. An integrative ChIP-chip and gene expression profiling to model SMAD regulatory modules. BMC systems biology. 2009;3:73. doi:10.1186/1752-0509-3-73. 
87. Guo W, Zhang M, Shen S, Guo Y, Kuang G, Yang Z, et al. Aberrant methylation and decreased expression of the TGF-beta/Smad target gene FBXO32 in esophageal squamous cell carcinoma. Cancer. 2014;120(16): 2412-23. doi:10.1002/cncr.28764.

88. Shishodia S, Aggarwal BB. Nuclear factor-kappaB activation mediates cellular transformation, proliferation, invasion angiogenesis and metastasis of cancer. Cancer Treat Res. 2004;119:139-73.

89. Aggarwal BB. Nuclear factor-kappaB: the enemy within. Cancer Cell. 2004; 6(3):203-8. doi:10.1016/j.ccr.2004.09.003.

90. Ahn KS, Aggarwal BB. Transcription factor NF-kappaB: a sensor for smoke and stress signals. Ann N Y Acad Sci. 2005;1056:218-33. doi:10.1196/annals. 1352.026 .

91. Sethi G, Sung B, Aggarwal BB. Nuclear factor-kappaB activation: from bench to bedside. Exp Biol Med (Maywood). 2008;233(1):21-31. doi:10.3181/0707-mr-196.

92. Garg A, Aggarwal BB. Nuclear transcription factor-kappaB as a target for cancer drug development. Leukemia. 2002;16(6):1053-68. doi:10.1038/sj.leu.2402482.

93. Karin M, van Hogerlinden M, Rozell BL, Ahrlund-Richter L, Toftgard R. Nuclear factor-kappaB in cancer development and progression squamous cell carcinomas and increased apoptosis in skin with inhibited Rel/nuclear factor-kappaB signaling. Nature. 2006;441(7092):431-6. doi:10.1038/nature04870.

94. van Hogerlinden M, Auer G, Toftgard R. Inhibition of Rel/Nuclear FactorkappaB signaling in skin results in defective DNA damage-induced cell cycle arrest and Ha-ras- and p53-independent tumor development. Oncogene. 2002;21(32):4969-77. doi:10.1038/sj.onc.1205620.

95. van Hogerlinden M, Rozell BL, Ahrlund-Richter L, Toftgard R. Squamous cell carcinomas and increased apoptosis in skin with inhibited Rel/nuclear factor-kappaB signaling. Cancer Res. 1999;59(14):3299-303.

96. Li J, Minnich DJ, Camp ER, Brank A, Mackay SL, Hochwald SN. Enhanced sensitivity to chemotherapy in esophageal cancer through inhibition of NF-kappaB. J Surg Res. 2006;132(1):112-20. doi:10.1016/j.jss.2005.10.005.

97. Li B, Li YY, Tsao SW, Cheung AL. Targeting NF-kappaB signaling pathway suppresses tumor growth, angiogenesis, and metastasis of human esophageal cancer. Mol Cancer Ther. 2009;8(9):2635-44. doi:10.1158/1535-7163.mct-09-0162.

98. Cheng $Y$, Geng $H$, Cheng SH, Liang $P$, Bai $Y$, Li J, et al. KRAB zinc finger protein ZNF382 is a proapoptotic tumor suppressor that represses multiple oncogenes and is commonly silenced in multiple carcinomas. Cancer Res. 2010;70(16):6516-26. doi:10.1158/0008-5472.can-09-4566.

99. Harris RA, Wang T, Coarfa C, Nagarajan RP, Hong C, Downey SL, et al. Comparison of sequencing-based methods to profile DNA methylation and identification of monoallelic epigenetic modifications. Nat Biotechnol. 2010;28(10):1097-105. doi:10.1038/nbt.1682.

100. Cordaux R, Batzer MA. The impact of retrotransposons on human genome evolution. Nat Rev Genet. 2009;10(10):691-703. doi:10.1038/nrg2640.

101. Saito K, Kawakami K, Matsumoto I, Oda M, Watanabe G, Minamoto T. Long interspersed nuclear element 1 hypomethylation is a marker of poor prognosis in stage IA non-small cell lung cancer. Clin Cancer Res. 2010; 16(8):2418-26. doi:10.1158/1078-0432.ccr-09-2819.

102. Murata A, Baba Y, Watanabe M, Shigaki H, Miyake K, Ishimoto T, et al. IGF2 DMRO methylation, loss of imprinting, and patient prognosis in esophageal squamous cell carcinoma. Ann Surg Oncol. 2014;21(4):1166-74. doi:10.1245/s10434-013-3414-7.

103. He YF, Li BZ, Li Z, Liu P, Wang Y, Tang Q, et al. Tet-mediated formation of 5-carboxylcytosine and its excision by TDG in mammalian DNA. Science. 2011;333(6047):1303-7. doi:10.1126/science.1210944.

104. Ito S, D'Alessio AC, Taranova OV, Hong K, Sowers LC, Zhang Y. Role of Tet proteins in $5 \mathrm{mC}$ to $5 \mathrm{hmC}$ conversion, ES-cell self-renewal and inner cell mass specification. Nature. 2010;466(7310):1129-33. doi:10.1038/nature09303.

105. Ito S, Shen L, Dai Q, Wu SC, Collins LB, Swenberg JA, et al. Tet proteins can convert 5-methylcytosine to 5-formylcytosine and 5-carboxylcytosine. Science. 2011;333(6047):1300-3. doi:10.1126/science.1210597.

106. Koh KP, Yabuuchi A, Rao S, Huang Y, Cunniff K, Nardone J, et al. Tet1 and Tet2 regulate 5 -hydroxymethylcytosine production and cell lineage specification in mouse embryonic stem cells. Cell Stem Cell. 2011; 8(2):200-13. doi:10.1016/j.stem.2011.01.008.

107. Tahiliani M, Koh KP, Shen Y, Pastor WA, Bandukwala H, Brudno Y, et al, Conversion of 5-methylcytosine to 5-hydroxymethylcytosine in mammalian
DNA by MLL partner TET1. Science. 2009;324(5929):930-5. doi:10.1126/science.1170116.

108. Zhang H, Zhang $X$, Clark E, Mulcahey M, Huang S, Shi YG. TET1 is a DNAbinding protein that modulates DNA methylation and gene transcription via hydroxylation of 5-methylcytosine. Cell Res. 2010;20(12):1390-3. doi:10.1038/cr.2010.156.

109. Chen K, Zhang J, Guo Z, Ma Q, Xu Z, Zhou Y, et al. Loss of 5hydroxymethylcytosine is linked to gene body hypermethylation in kidney cancer. Cell Res. 2016;26(1):103-18. doi:10.1038/cr.2015.150.

110. Murata A, Baba Y, Ishimoto T, Miyake K, Kosumi K, Harada K, et al. TET family proteins and 5-hydroxymethylcytosine in esophageal squamous cell carcinoma. Oncotarget. 2015;6(27):23372-82. doi:10.18632/oncotarget.4281.

111. Guo M, Ren J, Brock MV, Herman JG, Carraway HE. Promoter methylation of HIN-1 in the progression to esophageal squamous cancer. Epigenetics. 2008;3(6):336-41.

112. Jia Y, Yang Y, Brock MV, Cao B, Zhan Q, Li Y, et al. Methylation of TFPI-2 is an early event of esophageal carcinogenesis. Epigenomics. 2012;4(2):135-46. doi:10.2217/epi.12.11.

113. Wang JS, Guo M, Montgomery EA, Thompson RE, Cosby H, Hicks L, et al. DNA promoter hypermethylation of p16 and APC predicts neoplastic progression in Barrett's esophagus. Am J Gastroenterol. 2009;104(9):2153-60. doi:10.1038/ajg.2009.300.

114. Takeno S, Noguchi T, Fumoto S, Kimura Y, Shibata T, Kawahara K. E-cadherin expression in patients with esophageal squamous cell carcinoma: promoter hypermethylation, Snail overexpression, and clinicopathologic implications. Am J Clin Pathol. 2004;122(1):78-84. doi:10.1309/p2cd-fgu1-u7cl-v5yr.

115. Sato F, Shimada Y, Watanabe G, Uchida S, Makino T, Imamura M. Expression of vascular endothelial growth factor, matrix metalloproteinase-9 and Ecadherin in the process of lymph node metastasis in oesophageal cancer. Br J Cancer. 1999;80(9):1366-72. doi:10.1038/sj.bjc.6690530.

116. Lee EJ, Lee BB, Han J, Cho EY, Shim YM, Park J, et al. CpG island hypermethylation of E-cadherin (CDH1) and integrin alpha4 is associated with recurrence of early stage esophageal squamous cell carcinoma. Int J Cancer. 2008:123(9):2073-9. doi:10.1002/ijc.23598.

117. Fukuoka T, Hibi K, Nakao A. Aberrant methylation is frequently observed in advanced esophageal squamous cell carcinoma. Anticancer Res. 2006; 26(5A):3333-5.

118. Yamaguchi $S$, Kato $H$, Miyazaki $T$, Sohda M, Kimura $H$, Ide $M$, et al. RASSF1A gene promoter methylation in esophageal cancer specimens. Dis Esophagus. 2005;18(4):253-6. doi:10.1111/j.1442-2050.2005.00501.x.

119. Li B, Wang B, Niu LJ, Jiang L, Qiu CC. Hypermethylation of multiple tumorrelated genes associated with DNMT3b up-regulation served as a biomarker for early diagnosis of esophageal squamous cell carcinoma. Epigenetics. 2011;6(3):307-16.

120. Maesawa C, Tamura G, Nishizuka S, Ogasawara S, Ishida K, Terashima M, et al. Inactivation of the CDKN2 gene by homozygous deletion and de novo methylation is associated with advanced stage esophageal squamous cell carcinoma. Cancer Res. 1996;56(17):3875-8.

121. Esteller M, Garcia-Foncillas J, Andion E, Goodman SN, Hidalgo OF, Vanaclocha $V$, et al. Inactivation of the DNA-repair gene MGMT and the clinical response of gliomas to alkylating agents. N Engl J Med. 2000; 343(19):1350-4. doi:10.1056/nejm200011093431901.

122. Yan W, Herman JG, Guo M. Epigenome-based personalized medicine in human cancer. Epigenomics. 2015. doi:10.2217/epi.15.84.

123. Scolnick DM, Halazonetis TD. Chfr defines a mitotic stress checkpoint that delays entry into metaphase. Nature. 2000;406(6794):430-5. doi:10.1038/35019108.

124. Vogelstein B, Papadopoulos N, Velculescu VE, Zhou S, Diaz Jr LA, Kinzler KW. Cancer genome landscapes. Science. 2013;339(6127):1546-58. doi:10.1126/science.1235122

125. Bernstein BE, Stamatoyannopoulos JA, Costello JF, Ren B, Milosavljevic A, Meissner A, et al. The NIH Roadmap Epigenomics Mapping Consortium. Nat Biotechnol. 2010;28(10):1045-8. doi:10.1038/nbt1010-1045.

126. Adams D, Altucci L, Antonarakis SE, Ballesteros J, Beck S, Bird A, et al. BLUEPRINT to decode the epigenetic signature written in blood. Nat Biotechnol. 2012;30(3):224-6. doi:10.1038/nbt.2153.

127. Heyn H, Esteller M. DNA methylation profiling in the clinic: applications and challenges. Nat Rev Genet. 2012;13(10):679-92. doi:10.1038/nrg3270.

128. Toh Y, Egashira A, Yamamoto M. Epigenetic alterations and their clinical implications in esophageal squamous cell carcinoma. Gen Thorac Cardiovasc Surg. 2013;61(5):262-9. doi:10.1007/s11748-013-0235-3. 
129. Kelly TK, De Carvalho DD, Jones PA. Epigenetic modifications as therapeutic targets. Nat Biotechnol. 2010;28(10):1069-78. doi:10.1038/nbt.1678.

130. Goel A, Boland CR. Epigenetics of colorectal cancer. Gastroenterology. 2012; 143(6):1442-60. doi:10.1053/j.gastro.2012.09.032. e1

131. Yan W, Herman JG, Guo M. Epigenome-based personalized medicine in human cancer. Epigenomics. 2016;8(1):119-33. doi:10.2217/epi.15.84

132. Anupam K, Tusharkant C, Gupta SD, Ranju R. Loss of disabled-2 expression is an early event in esophageal squamous tumorigenesis. World J Gastroenterol. 2006;12(37):6041-5.

133. Mandelker DL, Yamashita K, Tokumaru Y, Mimori K, Howard DL, Tanaka $Y$ et al. PGP9.5 promoter methylation is an independent prognostic factor for esophageal squamous cell carcinoma. Cancer Res. 2005;65(11): 4963-8. doi:10.1158/0008-5472.can-04-3923.

134. Li LW, Yu XY, Yang Y, Zhang CP, Guo LP, Lu SH. Expression of esophageal cancer related gene 4 (ECRG4), a novel tumor suppressor gene, in esophageal cancer and its inhibitory effect on the tumor growth in vitro and in vivo. Int J Cancer. 2009;125(7):1505-13. doi:10.1002/ijc.24513.

135. Kawakami K, Brabender J, Lord RV, Groshen S, Greenwald BD, Krasna MJ et al. Hypermethylated APC DNA in plasma and prognosis of patients with esophageal adenocarcinoma. J Natl Cancer Inst. 2000;92(22):1805-11.

136. Jin Z, Mori Y, Yang J, Sato F, Ito T, Cheng Y et al. Hypermethylation of the nel-like 1 gene is a common and early event and is associated with poor prognosis in early-stage esophageal adenocarcinoma. Oncogene. 2007; 26(43):6332-40. doi:10.1038/sj.onc.1210461.

137. Ohta M, Mimori K, Fukuyoshi Y, Kita Y, Motoyama K, Yamashita K et al. Clinical significance of the reduced expression of $\mathrm{G}$ protein gamma 7 (GNG7) in oesophageal cancer. Br J Cancer. 2008;98(2):410-7. doi:10.1038/sj. bjc.6604124.

138. Jiang S, Linghu E, Zhan Q, Han W, Guo M. Methylation of ZNF331 Promotes Cell Invasion and Migration in Human Esophageal Cancer. Curr Protein Pept Sci. 2015;16(4):322-8.

\section{Submit your next manuscript to BioMed Central} and we will help you at every step:

- We accept pre-submission inquiries

- Our selector tool helps you to find the most relevant journal

- We provide round the clock customer support

- Convenient online submission

- Thorough peer review

- Inclusion in PubMed and all major indexing services

- Maximum visibility for your research

Submit your manuscript at www.biomedcentral.com/submit 